Jurnal Akuntansi \& Perpajakan, Volume 3, No. 1, Juli 2021

\title{
AKAD MUDHARABAH DAN STRATEGI MANAJEMEN UMKM DI MASA PANDEMI COVID-19 (Studi Kasus Warung Bakso Pak Roso Salemba Jakarta)
}

\author{
Akhmad Syafiudin ${ }^{1}$, Sumartini Abdul Latif ${ }^{2}$, Saprudin $^{3}$ \\ STEBank Islam Mr. Sjafruddin Prawiranagera ${ }^{1,2}$ \\ Sekolah Tinggi Ilmu Ekonomi Jayakarta ${ }^{3}$
}

\begin{abstract}
ABSTRAK
Kesuksesan dunia usaha tergantung pengelolaan manajemen yang baik, mulai dari tahap perencanaan, pengorganisasi, monitoring, evaluasi dan hasil yang hendak dicapai. Penelitian ini mengangkat masalah tentang Akad Mudarabah dan Manajemen Strategi UMKM dengan mengunakan metode penelitian kualitatif. Dari hasil penelitian, manajemen strategi yang dijalankan oleh warung bakso Pak Roso dinilai sangat efektif dalam menghadapi situasi pandemi walaupun tidak seperti hari biasa namun bakso pak Roso masih meraup keuntungan setiap bulan.Salah satu faktor yang medukungnya adalah ketepatan dalam memilih sumber pembiayaan usaha ketika sumber dana dari internal pengusaha tidak mencukupi. Strategi yang digunakan untuk meningkat keuntungan ditengah situasi covid-19 dengan memperbanyak promosi dan pemasaran melalui media sosial dqan aplikasi pesanan online yang dilakukan oleh konsumen.Strategi ini dapat menarik konsumen penikmat bakso untuk membeli bakso Pak Roso. Dengan demikian para pelaku usaha harus pandai mengelola usaha dan keuangannya ditengah ketidakpastian usaha sebagai akibat dari menurunya daya beli masyarakat.Dan pembiayaan syariah ini bisa menjadi salah satu solusinya.
\end{abstract}

Kata Kunci : Mudharabah, Manajemen Strategi dan UMKM

\section{ABSTRACT}

The success of the business world depends on good management, starting from the planning, organizing, monitoring, evaluation stages and the results to be achieved. This study raises the issue of the Mudarabah Agreement and MSME Strategic Management by using qualitative research methods. From the results of the study, the strategic management carried out by Pak Roso's meatball stall is considered very effective in dealing with the pandemic situation, although it is not like a normal day, Pak Roso's meatball still makes a profit every month. One of the supporting factors is the accuracy in choosing the source of business financing when the source of funds from the entrepreneur's internal is insufficient. The strategy used to increase profits in the midst of the covid-19 situation is to increase promotion and marketing through social media and online order applications made by consumers. This strategy can attract meatball connoisseurs to buy Pak Roso's meatballs. Thus, business actors must be good at managing their business and finances in the midst of business uncertainty as a result of the decline in people's purchasing power. And Islamic financing can be one solution.

Keywords: Mudharabah, Strategic Management and SMEs

Korespondensi: Akhmad Syafiudin, M.Ak. Sekolah Tinggi Ilmu Ekonomi dan Perbankan Islam Mr. Sjafruddin Prawiranegara Jl. Sunan Giri No. 1 Jakarta Timur - Indonesia 13220. Email: syafiudin.ahmad@gmail.com

\section{PENDAHULUAN}


Jurnal Akuntansi \& Perpajakan, Volume 3, No. 1, Juli 2021

Islam sangat menekankan bahwa kegiatan ekonomi manusia merupakan salah satu perwujudan dari pertanggungjawaban manusia sebagai khalifah di bumi agar keseimbangan dalam kehidupan dapat terus terjaga. Dalam konteks ajaran Islam, ekonomi Islam atau yang juga dikenal dengan ekonomi syariah merupakan nilai-nilai sistem ekonomi yang dibangun berdasarkan ajaran Islam, sebagaimana Abdullah (2004) mendefinisikan bahwa ekonomi islam adalah kumpulan prinsip-prinsip umum tentang ekonomi yang diambil dari Al-Qur'an dan Sunnah, dan pondasi ekonomi yang dibangun diatas dasar pokok-pokok tersebut dengan mempertimbangkan kondisi lingkungan dan waktu.

Kondisi ekonomi masyarakat yang lemah menuntut adanya jalan keluar karena kondisi masyarakat yang kurang baik, dapat menimbulkan dampak negatif terhadap kelangsungan hidup bermasyarakat. Menurut Shirazi (1994), kemiskinan dapat didefinisikan sebagai suatu situasi yang dihadapi oleh seorang individu di mana mereka tidak memiliki kecukupan sumber daya untuk memenuhi kebutuhan hidup yang nyaman, baik ditinjau dari sisi ekonomi, sosial, psikologis, maupun dimensi spiritual. Definisi kemiskinan ini dapat diartikan pada ketidakmampuan seseorang dalam memenuhi kebutuhan hidupnya. Beik dan Arsyianti (2016:71) menyatakan bahwa dalam pandangan
Islam ketika berbicara mengenai kemiskinan, maka yang ditekankan adalah upaya perhatian, pembelaan dan perlindungan terhadap kelompok miskin yang dilakukan oleh mereka yang terkategorikan sebagai kelompok mampu. Pihak yang di anggap mampu ini diharapkan dapat mengoptimalkan potensi yang dimiliki, baik secara individu maupun kelembagaan, sehingga tingkat kemiskinan masyarakat dapat diminimalisir. Salah satu upaya untuk menanggulangi kemiskinan adalah dengan memutuskan mata rantai kemiskinan melalui pengembangan microfinance yaitu pada sektor Usaha Kecil Menengah (UMKM) yakni unit usaha produktif yang berdiri sendiri, yang dilakukan oleh orang perorangan atau badan usaha di semua sektor ekonomi. Pemberdayaan UMKM perlu dioptimalisasikan dan di laksanakan lebih konsisten karena usaha-usaha kecil yang notabene merupakan sumber pendapatan bagi masyarakat.

Pesatnya perkembangan pelaku usaha mikro kecil dan menengah yang ada di Indonesia, sejalan dengan upaya pemerintah dalam mengentaskan kemiskinan sekaligus bisa menjadi sumber pendapataan negara (Saprudin, 2020). Disisi lain masih adanya beberapa hambatan dalam mengembangkan UMKM. Hambatan yang terjadi dapat berbeda di setiap daerah dengan daerah lainnya.Kendati demikian, persoalan mendasar yang di alami oleh pengusaha mikro, kecil dan menengah yaitu keterbatasan modal 
Jurnal Akuntansi \& Perpajakan, Volume 3, No. 1, Juli 2021

kerja, manajemen usaha, akses pasar dan keterampilan serta wawasan yang terbatas, mengingat keberadaan usaha ini kebanyakan dikelola oleh pengusaha kecil. Setiap pengusaha hamper mendambakan perkembangan usaha yang signifikan, dengan demikian pelakuusaha dapat mengembangkan lebih jauh dan lebih luas atas usahanya (Wujarso, 2020).

Salah satu yang menjadi pokok permasalahan bagi UMKM adalah permodalan. Hal ini akan menyebabkan ruang gerak UMKM semakin sempit, misalnya mengalami kesulitan dalam mengembangkan usahanya dikarenakan tidak mampu memenuhi pesanan dari konsumen dan akan kehilangan kesempatan untuk meningkatkan kuantitas dan kualitas produk yang dihasilkan. Banyak pelaku usaha yang terbentur masalah permodalan untuk memulai atau mengembangkan suatu usahanya. Walau saat ini begitu banyak bank-bank tersebar di Indonesia, namun pada kenyataannya sebagian besar belum mampu menyentuh masyarakat lapisan bawah dikarenakan ketidakmampuan dalam hal menyediakan persyaratan bankable, untuk menjawab permasalahan tersebut maka dalam Islam ada solusinya melalui akad mudharabah.

Konsep akad Mudharabahdapat menjadi salah satu alternative dalam meningkatkan usaha kecil menengah (UMKM) bagi masyarakat yang ingin melakukan usaha akan tetapi kurang memiliki modal untuk mengembangkan usaha tersebut. Jenis usaha kecil menengah (UMKM), merupakan suatu kegiatan bisnis yang bergerak diberbagai bidang usaha tertentu yang akan mampu mengatasi pengangguran dan kemiskinan di masyarakat. Peluang usaha kecil menengah (UMKM) apabila dikembangkan dan diawasi dengan baik sesuai dengan aturan-aturan yang harus dijalankan seorang pembisnis muslim maka akan mampu menjadi sektor yang handal dan mampu bersaing didunia seperti Masyarakat Ekonomi Asean (MEA) yang sudah kita hadapi saat ini. Kegiatan UMKM yang bergerak di Provinsi DKI Jakarta merupakan sektor informal yang mampu menggerakkan kegiatan pembangunan ekonomi, dengan bukti banyak dijumpai UMKM sebagai kegiatan produktif dalam menjawab tuntutan masyarakat.

DKI Jakarta merupakan suatu daerah yang dikenal daerah khusus ibu kota Negara dengan berbagai peraturan-peraturan yang tegas dalam setiap kegiatan masyarakat seperti kegiatan ekonomi. Di Provinsi DKI Jakarta UMKM sangat berperan penting untuk mengurangi pengangguran karena dengan adanya UMKM dapat menbuka kesempatan kerja.Namun pengembangan UMKM harus mebutuhkan strategi manajemen yang berkualitas sehingga mampu bertahan ditengah persaingan dunia usaha di Provinsi DKI Jakarta yang pertumbuhannya sangat pesat karena peluang tersebut banyak diminati oleh masyarakat. 
Jurnal Akuntansi \& Perpajakan, Volume 3, No. 1, Juli 2021

Kesuksesan setiap usaha baik besar maupun kecil, seperti UMKM.

\section{KAJIAN TEORI}

Konsep UMKM sangat berbeda dari suatu Negara dengan Negara lain. UMKM di Indonesia telah mendapat perhatian dan dibina pemerintah dengan membuat portofolio kementrian yaitu Menteri Koperasi dan UMKM (Manurung, 2008). Kementerian tersebut mengelompokkan UMKM menjadi tiga kelompok berdasarkan total asset, total penjualan tahunan, dan status usaha.

Kementerian Koperasi dan UMKM RI melaporkan bahwa secara jumlah unit, UMKM memiliki pangsa sekitar 99,99\% (62.9 juta unit) dari total keseluruhan pelaku usaha di Indonesia (2017), sementara usaha besar hanya sebanyak 0,01\% atau sekitar 5400 unit. Usaha Mikro menyerap sekitar 107,2 juta tenaga kerja $(89,2 \%)$, Usaha Kecil 5,7 juta (4,74\%), dan Usaha Menengah 3,73 juta (3,11\%); sementara Usaha Besar menyerap sekitar 3,58 juta jiwa. Artinya secara gabungan UMKM menyerap sekitar 97\% tenaga kerja nasional, sementara Usaha Besar hanya menyerap sekitar 3\% dari total tenaga kerja nasional.Persoalan lain yang menjadi perhatian: agar UMKM dapat berkembang dengan cepat, maka pembiayaannya harus dipikirkan oleh pengambil kebijkan.UMKM sudah selayaknya mendapat dana dari pasar modal bukan hanya dari bank atau rentenyr. Tetapi, skala kecil yang membuat para pengelolah securitas agak sulit membawahnya ke bursa, terutama peraturan bursa dan Bapepam yang menyatakan harus profit dalam dua tahun terakhir. Teknik yang terbaik dalam mendapatkan dana adalah melalui penerbitan obligasi secara bersama oleh UMKM. Bila investor ingin mendapatkan jaminan atas obligasi tersebut, pada UMKM dapat menjaminkan tempat usahannya (https://Kemenkopukm.go.id).

Manajemen adalah serangkaian penuh komitmen, keputusan, dan tindakan yang diperlukan oleh sebuah perusahaan untuk mencapai daya saing strategis dan menghasilkan diatas rata-rata. Input strategi relevan berasal dari analisis lingkungan eksternal dan internal, diperlukan untuk formulasi dan implementasi strategi yang efektif. Sebaliknya, tindakan strategis efektif adalah persyarat untuk dapat mencapai hasil yang diinginkan bagi daya saing strategis dan laba diatas rata-rata. Jadi, manajemen strategis digunakan untuk mencocokan kondisi pasar dan struktur persaingan yang selalu berubah dengan sumber daya, kapabilitas, dan kompetensi (sumber input srategis) perusahaan yang terus menerus berkembang. Tindakan srategisefektif yang dilakukan dalam konteks formulasi dan implementasi strategis yang diintegrasikan dengan cermas akan menghasilkan output strategis (outcome strategic) yang diinginkan (Duane, 2001). 
Jurnal Akuntansi \& Perpajakan, Volume 3, No. 1, Juli 2021

Menurut Zuriani Ritongan (2020) Manajemen strategi dapat dipahami sebagai proses pemilihan dan penerapan strategi-strategi. Sedangkan strategi adalah pola alokasi sumber daya yang memungkinkan organisasi-organisasi dapat mempertahankan kinerjanya. Menurut Grant (2008) dalam Handayani (2016) Strategi juga dapat diartikan sebagai keseluruhan rencana mengenai sumber daya-sumber daya untuk menciptakan suatu posisi menguntungkan. Dengan kata lain, manajemen strategi terlibat dengan pengembangan dan implementasi strategistrategi dalam kerangkan pengembangan keunggulan bersaing.

Dari beberapa pendapat tersebut di atas, maka manajemen strategi adalah serangkaian pengambilan keputusan yang dilakukan oleh individu atau suatu perusahaan dalam mewujudkan usaha dalam rangka mencapai tujuan yang telah ditargetkan.

Dalam kontesk suatu organisasi atau perusahaan, secara singkat istilah manajemenadalah apa yang dilakukan oleh manajer. Secara luas cakupannya apa saja yang telah direncanakan, distrukturkan, direalisasikan melalui tindakan, dan dalam tahap pengawasannya oleh kalangan manajerial bukan hanya mencapai sasaran-sasaran yang ditetapkan atau tujuan tertentu saja, melainkan harus bersifat efisien (tepat guna) hingga menjadi efektif atau tepat sasaran (Nurdiansyah, 2019).
Manajemen sebagai suatu ilmu, titik beratnya terdapat pada metode keilmuan. Memang yang mengikat semua ilmu adalah metode ilmu yang digunakan untuk mensistematisasikan seluruh pengetahuan yang sifatnya masi pragmatis. Batasan lain tentang ilmu bahwa ilmu yang merupakn suatu cara menganalisis yang mengizinkan para ahlinya untuk menyatakan suatu proposisi dalam bentuk kausalitas, yaitu apabila maka Dalam hubungan ini diketengahkan bahwa bagaimana sekumpulan pengetahuan harus disistematisasikan (Siswanto, 2005).

Ada empat landasan untuk mengembangkan manajemen menurut pandangan Islam, yaitu: Kebenaran, kejujuran, keterbukaan, keahlian. Seorang manajer harus memiliki empat sifat utama itu agar manajemen yang dijalankannya mendapatkan hasil yang maksimal. Yang paling penting dalam manajemen berdasarkan pandangan Islam adalah harus ada jiwa kepemimpinan. Kepemimpinan menurut Islam merupakan faktor utama dalam konsep manajemen (Didin Hafidhuddin dan Hendri Tanjung, 2014).

Manajemen menurut pandangan Islam merupakan manajemen yang adil. Batasan

adil adalah pemimpin tidak menganiaya bawahan dan bawahan tidak merugikan pemimpinmaupun perusahaan yang ditempati. Bentuk penganiayaan yang dimaksudkan adalahmengurangi atau tidak memberikan hak bawahan dan memaksa bawahan untuk bekerja 
Jurnal Akuntansi \& Perpajakan, Volume 3, No. 1, Juli 2021

melebihi ketentuan. Seyogyanya kesepakatan kerja dibuat untuk kepentingan bersama antara pimpinan dan bawahan. Jika seorang manajer mengharuskan bawahannya bekerja melampaui waktu kerja yang ditentukan, maka sebenarnya manajer itu telah mendzalimi bawahannya. Dan ini sangat bertentangan dengan ajaran Islam( Djalaluddin Ahmad, 2016).

Mudharabah adalah suatu transaksi pembiayaan yang berdasarkan syariah, yang juga digunakan sebagai transaksi pembiayaan perbankan Islam maupun lembaga keuangan syariah lainnya, yang dilakukan oleh para pihak berdasarkan kepercayaan.Kepercayaan merupakan unsur terpenting dalam transaksi pembiayaan mudharabah, karena dalam transaksi mudharabah, shahibul maal atau pemilik harta tidak diperbolehkan ikut campur di dalam pengelolaan proyek atau kegiatan usaha yang dijalankan oleh mudharib (Ascarya, 2019).Shahibul maal atau pemilik harta paling jauh hanya boleh memberikan saran-saran tertentu kepada mudharib dalam menjalankan atau mengelola kegiatan usahanya yang notabene dibiayai dengan danashahibul maal.

Akad mudharabah merupakan akad yang paling mewakili prinsip muamalah dalam Islam. Karena akad mudharabah sangat mewujudkan nilai-nilai keadilan muamalah melalui sistem bagi hasil. Sebuah sistem yang mempertemukan shahibul maal (pemilik harta) dengan para masyarakat-masyarakat profesional yang siap mengelolanya.

Menurut Fatwa Dewan Syariah Nasional No. 07/DSN-MUI/IV/2000, pembiayaan mudharabah adalah pembiayaan yang disalurkan oleh Lembaga Keuangan Syariah kepada pihak lain untuk usaha yang produktif.

Prinsip Mudharabah yaitu perjajian antara dua pihak dimana pihak pertama sebagai pemilik dana dan pihak kedua sebagai pengelolah dana untuk mengelola sesuatu kegiatan ekonomi dengan menyepakati misbah bagi hasil atas keuntungan yang akan diperoleh, sedangkan kerugian yang timbul adalah resiko pemilik dana sepanjang tidak terdapat bukti bahwa mudharib melakukan kecurangan atau tindakan yang tidak amanah (Mubarok, 2013).

Ekonomi Islam merupakan ilmu yang mempelajari perilaku ekonomi manusia yang perilakunya diatur berdasarkan aturan agama Islam dan didasari dengan tauhid sebagaimana dirangkum dalam rukun iman dan rukun Islam (Fauziah, 2014).

Selanjutnya, prinsip-prinsip ekonomi islam yang sering disebut dalam berbagai literatur ekonomi islam dapat dirangkum menjadi lima hal.

1. Hidup hemat dan tidak bermewah-mewah (abstain from wasteful and luxurious living).

2. Menjalankan usaha-usaha yang halal (permissible conduct).

3. Implementasi zakat (implementation of zakat). 
Jurnal Akuntansi \& Perpajakan, Volume 3, No. 1, Juli 2021

4. Penghapusan/pelarangan Riba (prohibition of riba).

5. Pelarangan maysir (judi/spekulasi).

Berdasarkan penjelasan diatas sistem ekonomi Islam berbeda dengan sistem ekonomi konvensional. Sesuai dengan paradigma ini, ekonomi dalam Islam tak lebih dari sebuah aktivitas hidup manusia. Jadi, dapat disimpulkan bahwa ketika ada istilah ekonomi Islam, yang berarti beraktivitas ekonomi menggunakan aturan dan prinsip Islam, dalam aktivitas ekonomi manusia, maka ia merupakan ibadah manusia dalamberekonomi. Dalam islam tidak ada sisi kehidupan manusia yang tidak ada nilai ibadahnya, sehingga tidak ada sisi hidup dan kehidupan manusia yang diatur dalam Islam (Buchori, 2019).

\section{METODOLOGI}

Metode penilitian yang digunakan dalam penelitian ini adalah metode penelitian dengan pendekatan kualitatif.Untuk memahami UKM terhadap akad Mudharabah ditinjau dari ekonomi Islam, maka jenis penelitian ini menggunakan jenis penelitian studi lapangan.Penelitian studi lapangan adalah penelitian yang dilakukan berdasarkan kriteria tempat untuk membuktikan benar atau tidaknya suatu teori dengan mengambil fakta-fakta dan data yang diperoleh pada objek penelitian (Nusa Putra, 2013).
Peneliti dapat mengamati secara mendalam aktivitas yang ada pada tempat tertentu untuk memperoleh gambaran yang lebih jelas.Sehingga dalam penelitian ini yang dijadikan objek penelitian adalah strategi manajemen dan akad mudharabahyang dilakukan oleh usaha warung bakso Pak Roso di tinjau dari ekonomi Islam.Adapun yang dijadikan subjek penelitian adalah Bapak Roso sebagai pemiliki usaha rumah makan tersebut.

Dalam penelitian ini, jenis data yang di dapatkan terdiri dari dua klasifikasi sumber, yakni data primer dan data sekunder.Adapun teknik pengumpulan data diambil melalui studi lapangan. Data yang peneliti peroleh dari lapangan menggunakan beberapa metode yaitu:

\section{Observasi}

2. Wawancara

3. dokumentasi

Dalam menganalisis data, peneliti menyusun dan menyeleksi data-data yang telah terkumpul secara sistematis dan dianalisis menggunakan metode pendekatan deskriptif kualitatif.Peneliti mendeskripsikan dari data-data yang didapat dilapangan, serta penjelasan yang dilakukan dalam kegiatan interview.yang berkaitan dengan penelitian. Dalam hal ini kaitannya bagaimana manejemen strategi yang diterapkan oleh UMKM dan pelaksanaan akad mudharabah sebagai pilihan alternatif terbaik oleh pengusaha UMKM dalam suatu kondisi tertentu. 
Jurnal Akuntansi \& Perpajakan, Volume 3, No. 1, Juli 2021

\section{III.PEMBAHASAN DAN HASIL}

Akad mudharabah sebagai salah konsep kerjasama perjanjian pembiayaan Usaha Mikro Kecil Menengah (UMKM) bagi dalam pengembangan bisnis yang sesuai syariat Islam yang membutuhkan modal.Perjanjian kerjasama akad murabahah menjadi kekuatan bagi pengembangan ekonomi Islam dalam dunia usaha.

Permodalan dengan pendekatan akad mudharabah itu mulai dilakukan oleh Pak Roso pada tahun 2017 .perjanjian akad mudharabah antara Bank Muamalat dengan pak Roso dilakukan untuk jangka waktu 5 tahun mulai tahun 2017 dan berakhir pada tahun 2022, dengan nominal pinjaman yang di sepakati sebesar Rp. 500.0000.000, (lima ratus juta rupiah). Adapun untuk pembangian keuntungan atau bagi hasilnya yaitu 50\% Pak Roso dan 50\% pihak bank.

Peluang usaha kuliner (makanan) bakso karena memiliki peluang pasar yang luas khususnya di wilayah kelurahan Paseban Jakarta Pusat maka Pak Roso mengisi peluang yang ada. Namun hal tersebut harus dikelola secara baik sehingga menghasilkan keuntungan sesuai dengan perjanjian akad mudharabah, bagi setiap pelaku bisnis pastinya dituntut untuk selalu teliti dalam mengkalkulasi segala bentuk pengeluaran dan pemasukan selama produksi, sebagaimana Usaha Mikro Kecil Menengah (UMKM) seperti yang di jalankan oleh Pak Roso dengan jenis usahanya yang bergerak pada kuliner (makanan) yaitu Bakso.

Sebagai salah satu makanan kesukaan sebagian besar masyarakat Indonesia, peluang usaha di sektor ini telah diminati oleh banyak orang terutama di wilayah Jakarta. Daya minat masyarakat yang sangat tinggi tersebut telah memotivasi Pak Roso untuk menjalankan peluang usaha yang dimaksud dalam dunia usaha manapun tentu memiliki persaingan, akan tetapi setiap pelaku usaha pasti mempunyai strategi dan manajemen agar usahanya tetap berkembang serta mampu bersaing dengan pembisnis atau pengusaha yang lain serta dapat memberikan keuntungan agar merangsang pembiayaan akad mudharabah yang lebih besar lagi untuk pengembanganusahanya.

Untuk mengurai bagaimana strategi manajemen usaha kecil menegah yang di jalankan oleh masyarakat seperti usaha bakso Pak Roso telah mengemukakan desain usaha sebagai berikut. Strategi manajemen untuk mencapai target perjanjian pembagian keuntungan sesuai akad mudharabah, maka warung bakso pak Roso mengunakan strategi pemasaran usaha baksonya agar bisa di ketahui oleh konsumen dengan cara pemasarannya lewat media sosial, seperti facebook, Instagram, twitter dan website serta templet sehingga target pembiayaan dengan konsep akad mudharabah sesuai terget. Menurut pak Roso, pada tahun 2017 telah 
Jurnal Akuntansi \& Perpajakan, Volume 3, No. 1, Juli 2021

dilakukan perjanjian akad mudharabah yang dibuat pihak Bank Muamalat dengan konsep pembagian keuntungan sehingga upaya untuk mencari keuntungan atas usahanya dengan memperkuat promosi atau pemasaran yang harus dilakukan akan tetapi sajian menu juga menjadi daya tarik bagi pelangang atau konsumen, untuk dapat membantu memasarkan kepada kerabat serta temannya karena kalau hanya pemasaran yang dilakukan namun menunya tidak menarik minat konsumen juga menjadi persoalan pengembangan usaha bakso sehingga karyawan yang mengelola menu harus selalu dikontrol agar nilai rasa maupun ciri khas masakan itu menarik pelanggan.

Usaha kami tidak ada yang menjadi pemodal, baik secara langsung maupun tidak langsung serta sebagian atau seluruh modal usaha yang kami jalankan akan tetapi ini murni sebagai usaha mandiri (milik sendiri) sehingga tidak diikat dengan perjanjian dalam bentuk apapun. Konsep perjanjian akad mudharabah yang dijalankan yaitu bagi keuntungan pada setiap bulan berjalan antara pak Roso dan pemilik modal usaha dengan skema masing-masing 50 persen antara pemodal dan pengelola usaha. (wawancara, 16 Februari 2021).

Selanjutnya menurut Ibu Suryati sebagai karyawan Bakso Pak Roso Mengatakan bahwa produksi atau masakan dan pemasaran selalu dikontrol untuk memastikan hasil yang memuaskan sehingga racikan menu bakso tidak mengecewakan pelanggan sebagaimana promosi yang dipublikasi pada media sosial karena jika bakso yang disajikan ke konsumen itu enak bagi pelanggan, maka mereka pasti akan selalu datang bahkan mengajak keluarga dan temannya berkujung ke Bakso Pak Roso, hal itu membantu kami dalam menarik minat pelanggan. (wawancara, 16 Februari 2021).

Hal senada juga disampaikan oleh Pak Surya karyawan Bakso Pak Roso mengemukakan bahwa manajemen strategi yang dilakukan adalah mulai dari soal modal, kreasi karyawan, kemudian pembacaan daya minat konsumen, penyajian menu bakso yang memikat pengunjung, pengelolaan racikan menu hingga pada promosi dimedia sosial seperti Facebook, Twitter, Instagram dan website, stiker dan template. Namun berkaitan dengan masakan menu itu sangat penting untuk menjaga pengembangan usaha bakso pak Roso. (Wawancara, 16 Februari 2021).

Kemudian menurut Pak Andre Karyawan Bakso Pak Roso menyatakan bahwa kontrol, pengawasan dan evaluasi selalu dilakukan untuk demi menjaga kepercayaan pelanggan atau konsumen karena selama bekerja di warung bakso Pak Roso, selalu dingatkan kepada kami sebagai karyawan agar menjalankan apa yang disampaikan. (wawancara, 16 Februari 2021).

Akad perjanjian mudharabah tetap dijalankan oleh Pak Roso sesuai dengan 
Jurnal Akuntansi \& Perpajakan, Volume 3, No. 1, Juli 2021

kesepakatan yang telah dilakukannya. Walaupun kondisi pelaku UMKM di tengah pandemi Covid19 saat ini mengalami kontraksi atau dampak yang sangat berpengaruh. Hal ini sangat dirasakan langsung oleh Bakso Pak Roso untuk mewujudkan kesepakatan akad mudharabah yang sudah disepakati dengan pemodal, memang sebelum pandemi banyak pengunjungnya, namun disituasi sekarang mengalami tekanan walaupun dengan manajemen strategi yang dirancang secara baik dari segi keuangan, pemasaran dan sumber dayanya. Situasi ini belum pernah terjadi seperti hari biasa (normal) dimana Pak Roso menargetkan keuntungan yang besar disetiap bulan dan tahun pembukuan keuntungan sehingga membangun kepercayaan dengan pemodal yang mendorong usaha bakso dengan mekanisme akad mudharabah.

\section{KESIMPULAN}

Dari pembahasan dan analisa yang telah peneliti lakukan terkait dengan akad mudharabah dan manajemen strategi warung bakso Pak Roso, maka dapat disimpulkan sebagai berikut:

1. Akad mudharabah sebagai salah satu konsep ekonomi Islam yang ikut mendorong kemajuan ekonomi Islam karena bantuan pembiayaan atau modal dalam bentuk kerjasama tersebut dapat memberikan semangat dunia usaha bagi yang kesulitan mendapatkan modal. Untuk meningkatkan usaha, maka manajemen strategi yang dijalakan oleh warung bakso Pak Roso yakni mulai dari perencanaan, kualitas bakso, produksi, dan pemasaran melalui media sosial.

2. Manajemen strategi yang dilakukan dinilai sangat efektif dalam menghadapi situasi pandemi walaupun keuntunggannya tidak seperti sebelulm ada pandemic Covid-19, Namun bakso pak Roso masih meraup keuntungan setiap bulan.

3. Kesulitan yang terjadi pada permodalan UMKM bisa disiasati dengan mencari sumber pendanaan atau pembiayaan usaha yang selektif dan efektif. Salah satunya melalui akan mudharabah maupun jenis pembiayaan lain yang peling sesuai dengan kondisi usaha.

\section{DAFTAR PUSTAKA}

At-Tariqi, Abdullah Abdul Husain, 2004, Ekonomi Islam Prinsip, Dasar, dan Tujuan. Yogyakarta:Magistra Insania Press Ascarya. 2019. Akad dan Produk Bank Syariah, Depok: PT. Raja Grafindo Persada

Beik, IS \& Arsyianti LD. 2016. Ekonomi Pembangunan Syariah. Depok: PT. Raja Grafindo Persada

Djalaluddin, Ahmad. 2016, Manajemen Qur'ani; Menerjemah Ibadah Ilahiyah dalam Kehidupan. Malang: Malang Press

Grant, Robert M. 2008. Analisis Strategi

Kontempporer. Penerbit Erlangga: Jakarta 
Jurnal Akuntansi \& Perpajakan, Volume 3, No. 1, Juli 2021

Hafidhuddin, Didin dan Hendri Tanjung, 2014, Manajemen Syariah, Jakarta: Gema Insani

Haris Nurdiansyah, 2019, Pengantar Manajemen, Bandung: Diandra Kreatif

Ika Yunia Fauziah, 2014, Prinsip Dasar Ekonomi

Islam, Jakarta: PT. Fajar Interpratama Mandiri

Jaih Mubarok, 2013, Akad Mudharabah, Bandung, Fokusmedia : Jakarta.

Manurung, A. Haymans. 2008. Modal Untuk Bisnis UKM. Jakarta: Kompas

Michael, R. Duane, dkk, 2018, Manajemen Strategi, Edisi Pertama. Jakarta: Salemba Empat

Nusa Putra, 2013, Metode penelitian Kalitatatif Manajemen, Jakarta: PT Raja Grafindo Persada

Nur S. Buchori, dkk, 2019, Manajemen Koperasi Syariah, Depok: PT. Raja Grafindo Persada Saprudin. Sianipar, A. Zulkarnain \& Wujarso, Riyanto. 2021. Effect of Business
Development and Taxation Knowledge on Taxpayer Compliance (MSME Case Study in Jakarta). Journal of Infoemation System, Applied, Management, Accounting and Research. Vol.5 No.1 Februari 2021

Shirazi, N.S, 1994. An Analysis of Pakistan's Poverty Problemand Its Alleviation Through Infaq. (Dissertation Unpublished). Islamabad: International Islamic University Siswanto, 2005, Pengantar Manajemen, Jakarta: PT. Bumi Aksara

Wujarso, Riyanto. Saprudin \& Napitupulu, R. Dameria. 2020. Pengaruh Pengetahuan Perpajakan dan Sanksi Pajak Terhadap Kepatuhan Wajib Pajak UMKM DI Jakarta. Jurnal STEI Ekonomi. Vol.29 No.02 Desember 2020

Zuriani Ritongan, 2020, Buku AjarManajemen Strategi, Yokyakarta: CV. Budi Utama www/http:Kementerian UMKM RI Tahun 2017. 